\title{
DC-DC converter Topologies for LED Driver Circuit: A Review
}

\author{
Deepak Agrawal ${ }^{1}$, Rajneesh Kumar Karn ${ }^{2}$, Deepak Verma ${ }^{3}$ and Rakeshwri Agrawal ${ }^{4}$ \\ ${ }^{1}$ Trinity Institute of Technology \& Research, Bhopal, India, \\ deepak.agrawa102@gmail.com \\ ${ }^{2}$ School of Engg. and Tech., Madhyanchal Professional University, Bhopal, India, \\ deanengg@mpu.ac.in \\ ${ }^{3}$ Birla Institute of Technology, Mesra, Jaipur Campus, India, \\ deepakverma16@gmail.com \\ ${ }^{4}$ Trinity Institute of Technology \& Research, Bhopal, India, \\ rakeshwri.pal19@gmail.com
}

Received: July 29, 2020. Revised: September 3, 2020. Accepted: September 5, 2020.

Published: September 9, 2020.

\begin{abstract}
It has been noticed that in commercial lighting, in terms of efficiency light-lamps based on lightemitting diodes(LEDs) are far better as compared to those where traditional high-pressure sodium (HPS) lamps which are still in use in major underdeveloped and developing areas worldwide in specifically street lighting. The LED driver is an electrical device which controls power flow to the single LED or a string of the LEDs or controls to the current flowing through the LEDs. Available conventional topologies for LED drivers have several demerits such as flickering issues, high losses, luminance problems, low power factor, more number of switches etc. So, the need of the hour is to develop efficient, compact, long lifetime, high power factor and flicker-free LED drivers. The LED have numerous advantages such as high luminous efficiency, life span and it has no mercury in its composition. Therefore, recently researchers of this area has been setting a goal to utilize LED as a good alternative to save electricity from major parts of this planet.

In this paper, various topologies of LED drivers are presented. This paper also portrays simulation of a LED driver which is based on the combination of the buckboost converter as power factor correction stage (PFC) and buck converter as dc-de power conversion (PC) stage. Both the stages are integrated using single switch only so it is basically integrated LED driver circuit.
\end{abstract}

Keywords-About four key words or phrases in alphabetical order, separated by commas.

\section{INTRODUCTION}

$\mathrm{T}$ HERE are more than 10 million Indian hawker/street vendors according to Ministry of Housing and Urban Poverty Alleviation [1], lighting is a major issue for them. Most of them are using 12 volt LED lights as they do not have the regular electrical supply. 12 volt LED is preferred as the 12 volt battery used in vehicles is easily available in the market. In the current scenario many researchers have been setting a goal to utilize LED lifespan with efficient and good driver circuit. Driver circuits provides the supply for the LED lamps, these circuits must be compatible enough so that they can convert electrical energy from the line and supply and process it with continuous current to the LED lights. Also, the driver lifespan and LEDs lifespan must be coherently maintained, so that lamps do not lose any of its main features, especially its own lifetime factor. W. Yang et al [2] presented a highly efficient multiple-output buck-type led driver which uses only single-inductor. Various buck converter based topology is also found in literature $[3,4,5,6$, $7,8,9]$. Power factor improvement is the main concern of the researcher working in this area, some of the researcher suggested topologies with improved power factor [9, 10]. Electrolytic Capacitor-Free topology is also available in literature which improves the lifetime of the driver $[11,4,12$, 13, 10, 14, 15, 16]. Amongst the esteemed researcher Cassio Gobbato et al [17] presented Integrated Topology of DC-DC Converter for LED Street Lighting System. This topology has been simulated and presented in this paper for 12 Volt LED lights. Topology presented in [17] is implemented as it is but 
the design parameters has been modified in accordance with the Indian scenario.

\section{TOPOLOGIES FOR LED DRIVER CIRCUIT}

In literature various topologies for LED drivers has been reported till date. In this paper these topologies have been presented.

\section{A. Integrated buck-flyback converter topology}

Guirguis Z. Abdelmessih, et al. [18], an integrated buck flyback converter topology is used to design the LED driver. The flyback converter is working in DCM mode to achieve high power factor. Parameters are redesigned in such a way that it has higher the efficiency, less output current ripple, Low THD and high - power factor than conventional IBFC converter. The efficiency achieved by this topology is $89 \%$, power factor 0.96 , THD is $16 \%$.

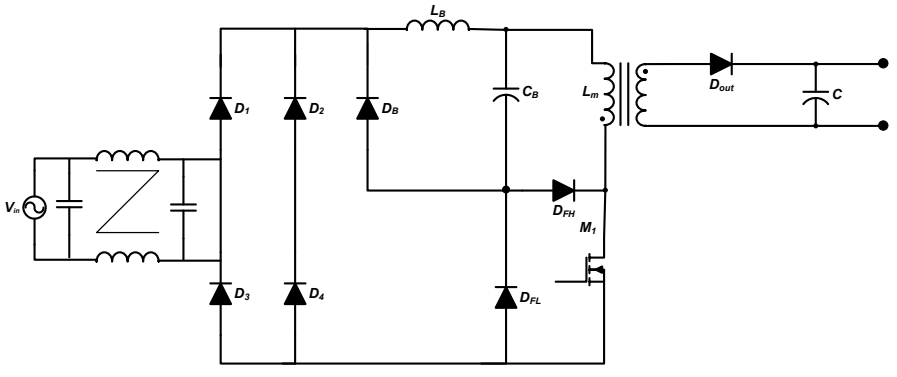

Fig. 2.2. Circuit of Integrated Buck Flyback LED driver with EMI Filter [18]

\section{B. Isolated 2 - channel LED driver with automatic current balance using capacitor}

K. Hwu and W. Jiang [19], suggested an isolated 2 - channel LED driver with automatic current balance using capacitor and zero dc magnetizing inductance current. In this topology, a transformer is provided for the isolation and also each winding has capacitor connected in series. Because of this the dc magnetization current is zero. Also, the capacitor in secondary winding works as current balancing in LED driver. This LED driver can be used for multi - channel LED driver without increasing the output voltage. The voltage stress on the MOSFET is less in this topology. The maximum efficiency achieved with this topology is $98.85 \%$.

\section{Single stage LED driver}

Y. Wang et al. [20], have designed single stage LED driver working in discontinuous conduction mode with primary side regulated characteristics to achieve high performance of the system such as high power density, high accuracy, high reliability, high power factor, high efficiency and low input current distortion. The calculation for different parameters, used in the implementation of the topology, is presented in this paper. For the variation in the input voltage from $90 \mathrm{~V}$ to $260 \mathrm{~V}$, power factor always remains greater than 0.95 and efficiency varies between $85 \%$ and $90.8 \%$.

\section{Single - stage LED driver featuring boost converter}

J. Ma et al. [21], depicted a single - stage LED driver featuring boost converter and a half-bridge LLC resonant converter. In this topology, the power factor correction is done by operating boost converter in discontinuous mode of conduction so that the driver has low THD and high pf. LLC resonant converter provides isolation as well as soft switching so that less switching losses are there. This LED driver can be employed for industrial lighting. This topology on full load has achieved $91.5 \%$ of efficiency.

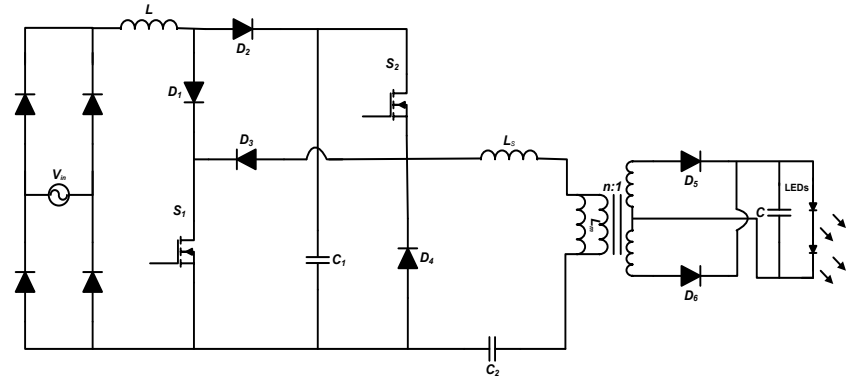

Fig. 2.1. Circuit of LED driver based on Boost circuit and LLC converter [21]

\section{E. Mixed color LED lighting system}

J. Huang, et al. [22], have shown that LED drivers used in applications such as the mixed color LED lighting system require constant current through each LED string and current flowing through each LED string should be controlled independently. For giving effect to this, a single stage LED driver with independent control of N- channel output current is developed. The working principle and independent current loop control strategy (ICCS) for 3-channel output LED driver is implemented in this paper. The design parameters for the implemented topology are elaborated in the paper.

\section{F. Self-oscillating soft switched LED driver}

B. M. Tehrani, et al. [23], have presented a self - oscillating soft switched LED driver which implements zero current switching (ZCS) at turn off instant of the switch. When variation in output voltage is around $33 \%$ then variation in current is only $10 \%$ it means output current flowing through LEDs remains almost constant when there is wide variation in output voltage so this topology does not require any current feedback. The topology presented in this paper does not need any power supply for control circuit. The main drawbacks of the topology are that it can operate for only low power applications i.e. less than $25 \mathrm{~W}$ and input current does not remain sinusoidal.

S. Zhang, X. Liu, Y. Guan, Y. Yao and J. M. Alonso [24], have depicted a LED driver topology in which switches are turned on and off by a modified ZVS control scheme. It is a single stage topology of LED driver based on Flyback and Class E converter. Class E converter is a resonant type of converter, so it has inherently soft switching. The Flyback converter is operated in discontinuous mode of conduction so that high power factor (pf) can be achieved with this topology and LED load is supplied by the Class E converter with wide range of duty cycle so that output current can be regulated at a constant frequency. Conventionally, the Class E converter has high drain - source voltage of the switch. To overcome this problem the converter is operated with variable duty cycle. 


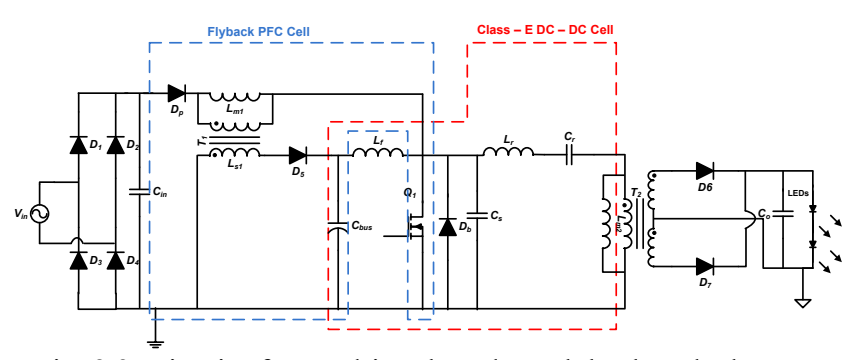

Fig. 2.3. Circuit of LED driver based on Flyback and Class - E converter [24]

\section{COMPARISON OF LED DRIVER TOPOLOGIES}

The comparison of various topologies presented in section II is presented in this section on the basis of various parameters: Converter type (represents the available topology of converter), number of switches (total number of switches used in the topology), efficiency power factor and total harmonics distortion (THD).

Table- I: Comparison of LED Driver topologies

\begin{tabular}{|l|c|c|c|c|c|}
\hline \multicolumn{1}{|c|}{ Topology } & Converter type & $\begin{array}{c}\text { No. of } \\
\text { switches }\end{array}$ & Efficiency & $p f$ & THD \\
\hline $\begin{array}{l}\text { Loss analysis for } \\
\text { efficiency } \\
\text { improvement of the } \\
\text { IBFC LED driver [18] }\end{array}$ & $\begin{array}{c}\text { Integrated Buck- } \\
\text { Flyback }\end{array}$ & $\begin{array}{c}\text { MOSFE } \\
\text { T (x1) }\end{array}$ & $89 \%$ & 0.96 & 16 \\
\hline $\begin{array}{l}\text { 2-channel LED Driver } \\
\text { [19] }\end{array}$ & $\begin{array}{c}\text { Boost Converter } \\
\text { with galvanic } \\
\text { isolation }\end{array}$ & 01 & $98.85 \%$ & - & - \\
\hline $\begin{array}{l}\text { Primary side regulated } \\
\text { LED driver [20] }\end{array}$ & $\begin{array}{c}\text { Flyback } \\
\text { converter }\end{array}$ & 01 & $91 \%$ & 0.99 & 8.3 \\
\hline $\begin{array}{l}\text { LED driver based on } \\
\text { Boost circuit and LLC } \\
\text { converter [21] }\end{array}$ & $\begin{array}{c}\text { Boost Converter } \\
\text { with LLC } \\
\text { Resonant } \\
\text { Converter }\end{array}$ & 02 & $91.5 \%$ & 0.94 & - \\
\hline $\begin{array}{l}\text { Single stage series } \\
\text { type LED drivers [22] }\end{array}$ & $\begin{array}{c}\text { Buck-boost } \\
\text { converter }\end{array}$ & 04 & - & - & 4.78 \\
\hline $\begin{array}{l}\text { Self-oscillating soft } \\
\text { switched LED drivers } \\
\text { [23] }\end{array}$ & - & 04 & $90 \%$ & 0.95 & 3.2 \\
\hline $\begin{array}{l}\text { LED driver based on } \\
\text { class E converter [24] }\end{array}$ & $\begin{array}{c}\text { Flyback and } \\
\text { Class E converter }\end{array}$ & 01 & $91.6 \%$ & 0.99 & 5 \\
\hline
\end{tabular}

\section{TOPOLOGY IMPLEMENTED}

The topology given in [17] is implemented in MATLAB Simulink in this paper and the circuit diagram of this topology is given in Fig. 1.

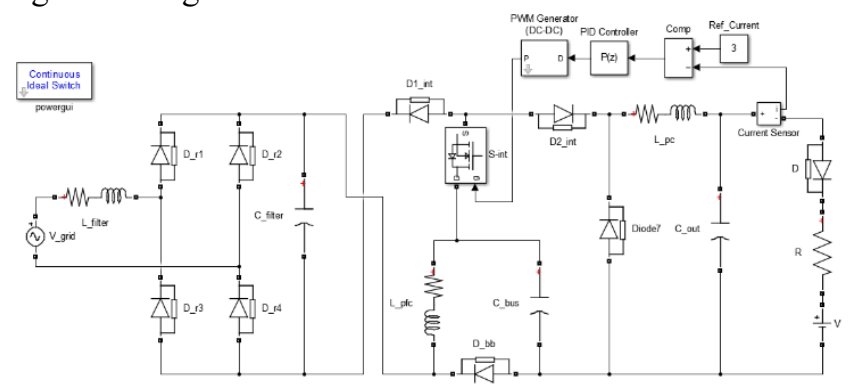

Fig. 1. Circuit diagram of integrated DC-DC converters [17].
The electrical modeling of LED as shown in the Fig. 2 is a series connection of an ideal diode (D), a resistor (R) and a voltage source $(\mathrm{V})$. Voltage source characterizes the minimum voltage required to make LED forward biased.

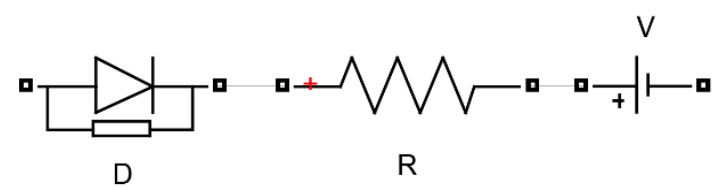

Fig. 2. Electrical modeling of LED in MATLAB Simulink

Integrated topology [17, 25]: Quanming Luo et al [25] present Single-Stage AC-DC LED Driver which is integration of two DC-DC converters. First power factor correction (PFC) unit which is Buck-Boost converter operating in discontinuous conduction mode (DCM) and second is an isolated DC-DC unit with a voltage rectifier. This integration is possible by sharing the same power switch and both the converters must operate in same duty ratio and same switching frequency.

T-type inverted presented in [17] and [25] shown in Fig. 1 is the series connection of buck-boost and buck converters shown in Fig. 3 and Fig. 4. In this topology the drains of the switches $S_{b b}$ and $S_{b}$ share the same node thus replacing the $S_{b b}$ and $S_{b}$ switches by $S_{i n t}$ switch and adding two diodes $D_{\text {lint }}$ and $D_{2 i n t}$ as shown in Fig. 1 .

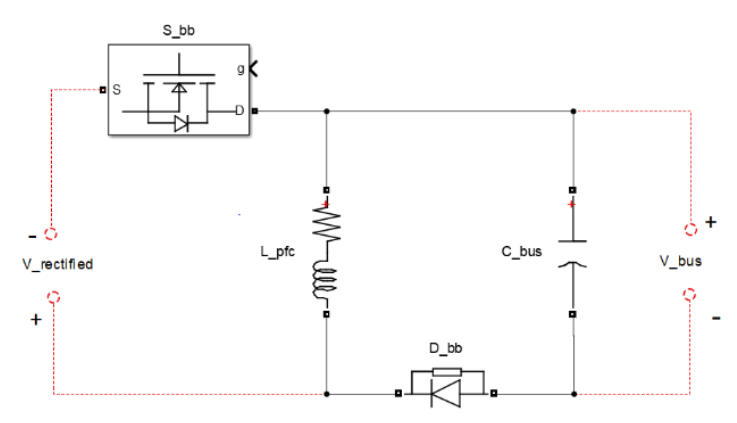

Fig. 3. Buck-boost converter

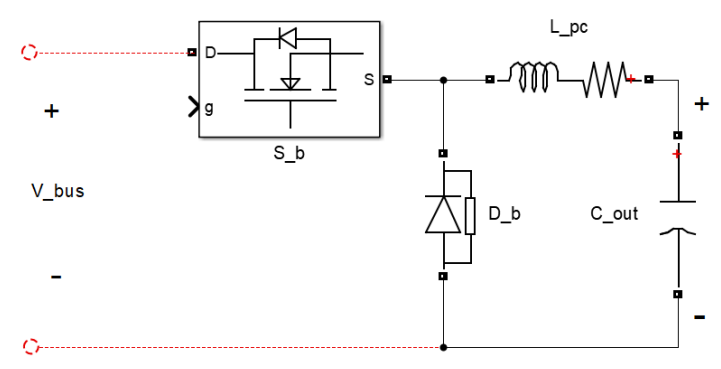

Fig. 4. Buck converter

\section{Design Parameters}

Design parameters used in the base paper [17] is shown in table 2 below: 
Table- II: Design parameters used in [17]

\begin{tabular}{|l|l|l|}
\hline \multicolumn{1}{|c|}{ Symbol } & \multicolumn{1}{c|}{ Specification } & \multicolumn{1}{c|}{ Value } \\
\hline$V_{\text {GRID }}$ & Mains voltage (RMS) & $127 \mathrm{~V}$ \\
\hline$f r$ & Mains frequency & $60 \mathrm{~Hz}$ \\
\hline Po & Output power (each module) & $25 \mathrm{~W}$ \\
\hline Ileds & Output current (average) & $500 \mathrm{~mA}$ \\
\hline Vbus & PFC output voltage (average) & $170 \mathrm{~V}$ \\
\hline Vout & PC output voltage (average) & $51 \mathrm{~V}$ \\
\hline$\Delta$ Ileds & LEDs current ripple & $100 \mathrm{~mA}-$ \\
\hline$\Delta$ Vbus & PFC output voltage ripple & $85 \mathrm{~V}-50 \%$ \\
\hline$\Delta$ Vout & PC output voltage ripple & $1.02 \mathrm{~V}-2 \%$ \\
\hline$f s$ & Switching frequency & $60 \mathrm{kHz}$ \\
\hline
\end{tabular}

Design parameters shown in table 1 are modified according to Indian hawker/street vendors lighting requirements. As discussed in the introduction section Indian hawkers already using $12 \mathrm{~V}$ LED lights which are directly connected to a $12 \mathrm{~V}$ battery. The LED driver presented in this paper also uses $12 \mathrm{~V}$ output to fulfill the hawkers lighting demand. The LED strip or light can be used directly with $12 \mathrm{~V}$ battery when grid is unavailable and once the grid is available one can used this driver to light the same LED. The modified design parameters used in this paper is shown in table 3 .

Table- III: Design parameters used in this paper

\begin{tabular}{|l|l|l|}
\hline Symbol & \multicolumn{1}{|c|}{ Specification } & \multicolumn{1}{c|}{ Value } \\
\hline$V_{\text {GRID }}$ & Mains voltage (RMS) & $230 \mathrm{~V}$ \\
\hline$f r$ & Mains frequency & $50 \mathrm{~Hz}$ \\
\hline Po & Output power & $25 \mathrm{~W}$ \\
\hline Ileds & Output current (average) & $2.2 \mathrm{~A}$ \\
\hline Vbus & PFC output voltage (average) & $85 \mathrm{~V}$ \\
\hline Vout & PC output voltage (average) & $12 \mathrm{~V}$ \\
\hline$\Delta$ Ileds & LEDs current ripple & $100 \mathrm{~mA}-20 \%$ \\
\hline$\Delta$ Vbus & PFC output voltage ripple & 85.6 to $87.6 \mathrm{~V}(2.35 \%)$ \\
\hline$\Delta$ Vout & PC output voltage ripple & $\begin{array}{l}12.356 \text { to } 12.346- \\
(0.08 \%)\end{array}$ \\
\hline$f_{s}$ & Switching frequency & $60 \mathrm{kHz}$ \\
\hline
\end{tabular}

\section{Simulation AND ReSUlts}

MATLAB Simulation of the integrated topology is presented in Fig. 1; results are discussed in this section. Fig. 5 shows the time response of load current, it shows the current is stable at the value of $2.25 \mathrm{~A}$.

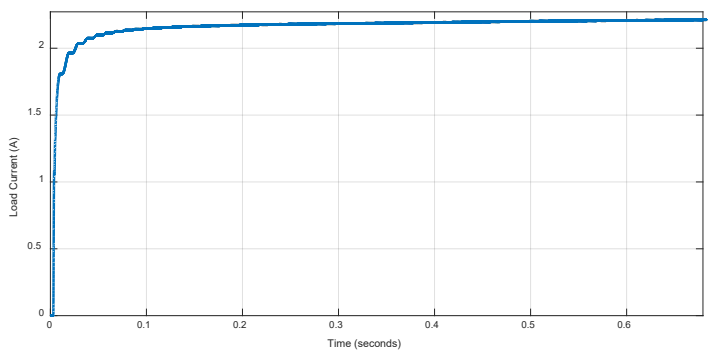

Fig. 5. Load current vs time curve

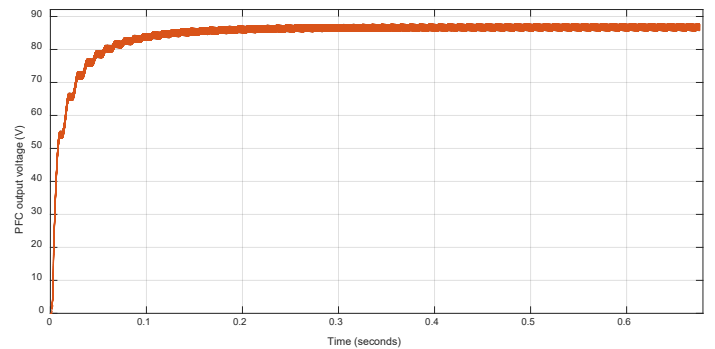

Fig. 6. PFC output voltage vs time curve

Fig. 6 shows the output voltage after PFC stage and Fig. 6 shows the ripple in voltage after PFC stage.

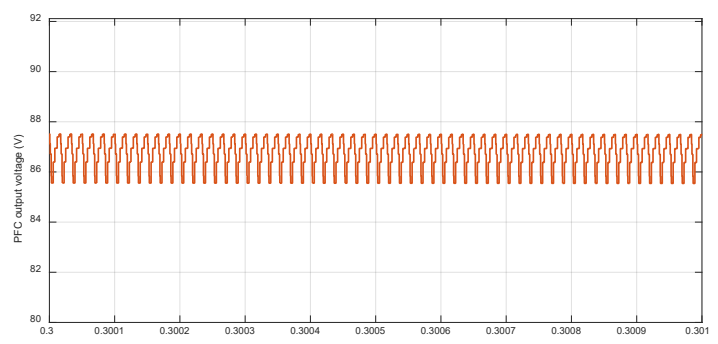

Fig. 6. Ripple in PFC output voltage.

Fig. 7 shows the output power with respect to time plot which is stable near the 25.25 watts. This power is sufficient for the lighting purpose of the Indian hawkers.

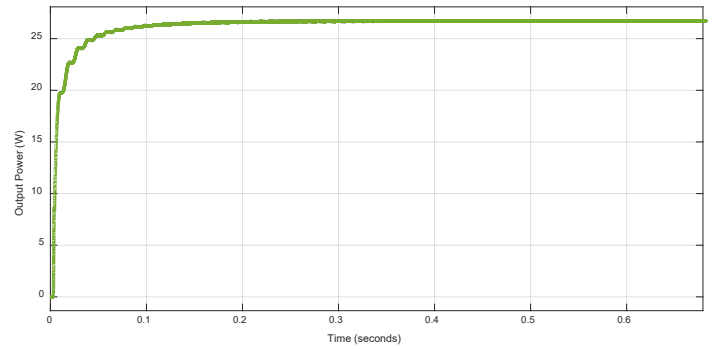

Fig. 7. Output power vs time curve.

Fig. 8 shows the output voltage at the LED end which is stabled at 12 Volts. 


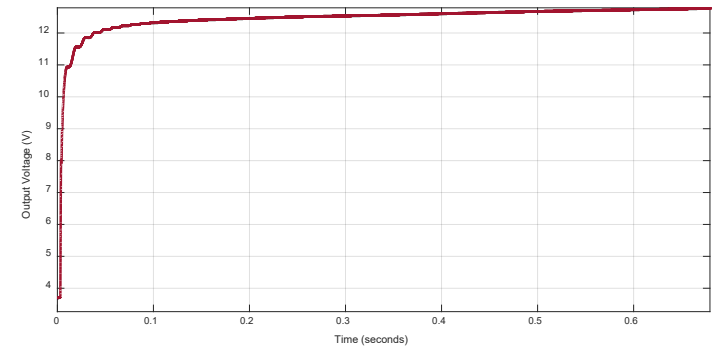

Fig. 8. Output voltage vs time curve.

Fig. 9 shows the ripple in the output voltage which is less than $1 \%$ hence the minimum flickering occurs in the LED light.

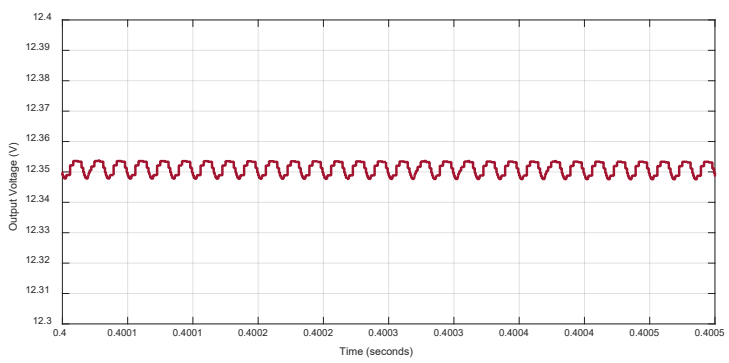

Fig. 9. Ripple in output voltage.

\section{CONCLUSION}

In this paper integrated topology of DC-DC converter is presented for LED driver circuit, this topology has been presented by Cassio Gobbato et al however the designed parameters have been changed in accordance with the Indian hawker/street vendors. About 10 million Indian hawker/street vendors in India having irregular power supply. The topology is modified in accordance with them and the output voltage is stabled at 12 Volt DC which can fulfill their lighting needs with less than $1 \%$ ripples in the output.

\section{References}

[1] Ministry of Housing and Urban Poverty Alleviation, "http://mohua.gov.in".

[2] W. Yang, H. Yang, C. Huang, K. Chen and Y. Lin, "A HighEfficiency Single-Inductor Multiple-Output Buck-Type LED Driver With Average Current Correction Technique," in IEEE Transactions on Power Electronics, vol. 33, no. 4, pp. 3375-3385, April 2018.

[3] G. Z. Abdelmessih, J. M. Alonso and W. Tsai, "Analysis and Experimentation on a New High Power Factor Off-Line LED Driver Based on Interleaved Integrated Buck Flyback Converter," in IEEE Transactions on Industry Applications, vol. 55, no. 4, pp. 4359-4369, July-Aug. 2019.

[4] C. Shin et al., "Sine-Reference Band (SRB)-Controlled Average Current Technique for Phase-Cut Dimmable AC-DC Buck LED Lighting Driver Without Electrolytic Capacitor," in IEEE Transactions on Power Electronics, vol. 33, no. 8, pp. 6994-7009, Aug. 2018.

[5] D. Do, H. Cha, B. L. Nguyen and H. Kim, "Two-Channel Interleaved Buck LED Driver Using Current-Balancing Capacitor," in IEEE Journal of Emerging and Selected Topics in Power Electronics, vol. 6, no. 3, pp. 1306-1313, Sept. 2018.
[6] G. Z. Abdelmessih, J. M. Alonso and M. A. Dalla Costa, "Loss Analysis for Efficiency Improvement of the Integrated BuckFlyback LED Driver," in IEEE Transactions on Industry Applications, vol. 54, no. 6, pp. 6543-6553, Nov.-Dec. 2018.

[7] M. Kim, "High-Performance Current-Mode-Controller Design of Buck LED Driver With Slope Compensation," in IEEE Transactions on Power Electronics, vol. 33, no. 1, pp. 641-649, Jan. 2018.

[8] Y. Wang, S. Gao, S. Zhang and D. Xu, "A Two-Stage QuasiResonant Dual-Buck LED Driver With Digital Control Method," in IEEE Transactions on Industry Applications, vol. 54, no. 1, pp. 787-795, Jan.-Feb. 2018.

[9] X. Liu, Y. Wan, Z. Dong, M. He, Q. Zhou and C. K. Tse, "BuckBoost-Buck-Type Single-Switch Multistring Resonant LED Driver With High Power Factor and Passive Current Balancing," in IEEE Transactions on Power Electronics, vol. 35, no. 5, pp. 5132-5143, May 2020.

[10] H. Dong, X. Xie, L. Jiang, Z. Jin and X. Zhao, "An Electrolytic Capacitor-Less High Power Factor LED Driver Based on a "Oneand-a-Half Stage" Forward-Flyback Topology," in IEEE Transactions on Power Electronics, vol. 33, no. 2, pp. 1572-1584, Feb. 2018

[11] J. Liu, H. Tian, G. Liang and J. Zeng, "A Bridgeless Electrolytic Capacitor-Free LED Driver Based on Series Resonant Converter With Constant Frequency Control," in IEEE Transactions on Power Electronics, vol. 34, no. 3, pp. 2712-2725, March 2019.

[12] H. Wu, S. Wong, C. K. Tse and Q. Chen, "A PFC Single-CoupledInductor Multiple-Output LED Driver Without Electrolytic Capacitor," in IEEE Transactions on Power Electronics, vol. 34, no. 2, pp. 1709-1725, Feb. 2019.

[13] H. Wu, S. Wong and C. K. Tse, "A More Efficient PFC SingleCoupled-Inductor Multiple-Output Electrolytic Capacitor-Less LED Driver With Energy-Flow-Path Optimization," in IEEE Transactions on Power Electronics, vol. 34, no. 9, pp. 9052-9066, Sept. 2019.

[14] P. Fang, S. Webb, Y. Liu and P. C. Sen, "Single-Stage LED Driver Achieves Electrolytic Capacitor-Less and Flicker-Free Operation With Unidirectional Current Compensator," in IEEE Transactions on Power Electronics, vol. 34, no. 7, pp. 6760-6776, July 2019.

[15] S. Pervaiz, A. Kumar and K. K. Afridi, "A Compact ElectrolyticFree Two-Stage Universal Input Offline LED Driver With Volume-Optimized SSC Energy Buffer," in IEEE Journal of Emerging and Selected Topics in Power Electronics, vol. 6, no. 3, pp. 1116-1130, Sept. 2018.

[16] C. Ye, P. Das and S. K. Sahoo, "Inductive decoupling-based multichannel LED driver without electrolytic capacitors," in IET Power Electronics, vol. 12, no. 11, pp. 2771-2779, 1892019.

[17] C. Gobbato, S. V. Kohler, I. H. de Souza, G. W. Denardin and J. d. P. Lopes, "Integrated Topology of DC-DC Converter for LED Street Lighting System Based on Modular Drivers," in IEEE Transactions on Industry Applications, vol. 54, no. 4, pp. 38813889, July-Aug. 2018.

[18] G. Z. Abdelmessih and J. M. Alonso, "Loss analysis for efficiency improvement of the integrated buck-flyback converter for LED driving applications," 2017 IEEE Industry Applications Society Annual Meeting, Cincinnati, OH, 2017, pp. 1-8.

[19] K. Hwu and W. Jiang, "Expandable two-channel LED driver with galvanic isolation and automatic current balance," in IET Power Electronics, vol. 11, no. 5, pp. 825-833, 152018.

[20] Y. Wang, S. Zhang, J. M. Alonso, X. Liu and D. Xu, "A SingleStage LED Driver with High-Performance Primary-SideRegulated Characteristic," in IEEE Transactions on Circuits and Systems II: Express Briefs, vol. 65, no. 1, pp. 76-80, Jan. 2018.

[21] J. Ma, X. Wei, L. Hu and J. Zhang, "LED Driver Based on Boost Circuit and LLC Converter," in IEEE Access, vol. 6, pp. 4958849600, 2018.

[22] J. Huang, Q. Luo, Q. He, A. Zu and L. Zhou, "Analysis and Design of a Digital-Controlled Single-Stage Series-Type LED Driver with Independent N-Channel Output Currents," in IEEE Transactions on Power Electronics, vol. 34, no. 9, pp. 9067-9081, 
[23] B. M. Tehrani, M. A. Chamali, E. Adib, M. R. Amini and D. G. Najafabadi, "Introducing Self-Oscillating Technique for a SoftSwitched LED Driver," in IEEE Transactions on Industrial Electronics, vol. 65, no. 8, pp. 6160-6167, Aug. 2018.

[24] S. Zhang, X. Liu, Y. Guan, Y. Yao and J. M. Alonso, "Modified zero-voltage-switching single-stage LED driver based on Class E converter with constant frequency control method," in IET Power Electronics, vol. 11, no. 12, pp. 2010-2018, 16102018.

[25] Q. Luo, J. Huang, Q. He, K. Ma and L. Zhou, "Analysis and Design of a Single-Stage Isolated AC-DC LED Driver With a Voltage Doubler Rectifier," in IEEE Transactions on Industrial Electronics, vol. 64, no. 7, pp. 5807-5817, July 2017.

[26] Ngoc Thuy Pham, "Speed Tracking of Field Oriented Control SPIM Drive using (BS_SOSM) Nonlinear Control Structure" WSEAS Transactions on Systems and Control, Volume 14, 2019,
[27] Cornelia A. Bulucea, Doru A. Nicola, Carmen A. Bulucea, "Comprehensive Analysis Dedicated to Three-phase Power Transformer With Three-phase Bridge in AC/DC Traction Substations" WSEAS Transactions on Systems and Control, Volume 14, 2019, Art. \#39, pp. 306-318

[28] Hussein. D. Al-Majali, Bilal. H. Al-Majali, "Fast and Continuous Control of a Modified HVDC Converter" WSEAS Transactions on Systems and Control, Volume 14, 2019, Art. \#41, pp. 326-332

\section{Creative Commons Attribution License 4.0 (Attribution 4.0 International, CC BY 4.0)}

This article is published under the terms of the Creative Commons Attribution License 4.0 https://creativecommons.org/licenses/by/4.0/deed.en_US 